\title{
Indicators Coefficient Calculation Using Technoware, Humanware, Organware and Infoware
}

\author{
Ikhsan Siregar, Rahmi M. Sari, Khalida Syahputri, Indah Rizkya, Yusuf Hanifiah, \\ Mohammad Anggia Muchtar
}

\author{
Department of Industrial Engineering, Faculty of Engineering, , \\ Department of Information Technology, Faculty of Computer Science and Information Technology \\ University of Sumatera Utara, Medan, Indonesia \\ ikhsan.siregar@usu.ac.id
}

\begin{abstract}
Technological developments and competition between the manufacturing industries in Indonesia is currently growing very rapidly. Every manufacturing industry competing in the meet consumer demand increasingly varied. Technology is an important factor in enhancing this competition. Research made in companies engaged in the processing of natural rubber latex into rubber crumb, because Indonesia is one of the countries producing crumb rubber. A problem faced by the company is an imbalance use of technology in the production process. Technological imbalance here lies in the weakness of the storage system of information on the production are still using bookkeeping methods while machinery used for production is already a semi-automatic machines. In addition, many similar industries require companies to maintain product quality to enhance the competitiveness of enterprises. The purpose of this study was to measure the level of technological capability in the company. Completion method used is measurement technology using methods techno metric that which is obtained that the company has a TCC of 0.57 . This indicates that the use of technology in general at the company had reached 57\%. Companies still need improvements to increase the utilization of the technology that will ultimately have an impact on company productivity
\end{abstract}

Keywords: Technology; level of technological capability; technometric; utilization technology

\section{INTRODUCTION}

Indonesia is the second largest natural rubber producer in the world after Thailand. But the availability of raw materials only able to reach 3 million tons per year. As a result, there is excess demand to be met as much as 1 million tons per year. This causes a loss of rubber farmers in Indonesia, because the rubber products progressively decreased.

Through this research will be applied techno metric method, where this method would like to see the extent to which indicators the company's technology capabilities so that production is increasing and the rubber growers can continuously be able to sell rubber to the company to meet the domestic market needs even abroad.

In previous research, techno metric method used to establish technology standards; this is done for a patent license with the principle of proportionality. (1). Other study related to techno metric is

viewed technology strategic partner for the company. (2). Other studies that look at that technology transfer is indispensable in the development of the model. (3). From the above study, we can see that the technology is very important for the development of the company and the economy. In fact, not only that, in another study mentions that human ware also influential in Trends in design philosophy (4). While the big companies RICOH also been the object of research, in which Ricoh factory for the production of Plain Paper Copier (PPC) has developed a new production system using hardware, software and "human ware" (5). Other studies are no less important is the knowledge gap between the information rich and the working poor in the information technology industry and 
high-yield economic gap, employment gap, social and cultural gap and the gap value. One way to bridge this gap is to develop human ware - retraining programs - making it accessible to all workers, and thereby maintain them. (6). Thus we can say that technology is an important element in a manufacturing company, and for global competition. Where in the research states that Understanding and acquire the technology assets to global competition is very important. (7). Research in Iran was also mentioned that the technology must be continuously evaluated, where the study mentioned that the wind energy status of Iran: Iran Evaluate technology capabilities in the manufacture of wind turbines. (8).

Through research mentioned above it is clear that research should always update and evaluated for the progress of a company whose securities for economic development.

Therefore this study took a sample of the rubber company in Indonesia, where after a survey crew discovered that the company has used the production machine is almost the same as other rubber companies in Indonesia.

The production process is done by using the production machines working semi-automatic. The production process is ongoing to meet increasing demand. The main problem is an imbalance use of technology in the production process. Technological imbalance here lies in the weakness of the storage system of information on the production are still using bookkeeping methods while machinery used for production is already a semi-automatic machines. In addition, many similar industries require companies to maintain product quality to enhance the competitiveness of enterprises.

\section{METHOD}

The method used in this research is the method techno metric. This method is very important and suitable to be applied for techno metric been used in many aspects of the analysis to the measurement technology. The fourth component is the technology base techno ware, human ware info ware and organ ware is to transform inputs into outputs that have variations and levels of varying complexity. Techno ware will not be able to work alone and useless if human ware not use it. Human ware has a key role in the transformation process. Human ware cause techno ware become more productive. Info ware represent emerging science. Organ ware coordinate info ware, human ware and techno ware in a process of transformation that the process is efficient. The increase in sophistication techno ware used, demanding human ware have the ability to operate techno ware.

Human ware component assessment was conducted using questionnaires technology which is based on a generic method of UNESCAP, which includes the questionnaire component evaluation criteria

Technology, the degree of sophistication of the technology component questionnaire, a questionnaire criteria for state of the art. The questionnaire used is based on the generic criteria of UNESCAP (1989).

In techno ware components, reviewed the machines used in the production process where the machines used are semi-automatic machine output in 2010. In human ware component, in terms of workers at the company where the review was initiated on the board until the labor / mobile workers. In info ware components, machine operating procedures are reviewed, quality of materials and product testing, engine maintenance and the number of products to be produced which is still using bookkeeping methods. In organ ware components, control systems to be reviewed and calling in running the transformation process through clear division of tasks and appear in the organizational structure. By knowing the level of each of these technologies, companies can improve the technology components are still less so to do improvements on existing technology in the company.

To determine the level of technological capabilities of the company it is necessary to further study the assessment of the technological sophistication of all 
components of the technology. The method used the method techno metric. By doing this study, later to become inputs for the plant in the form proposed performance improvement technology components that they have or develop technology innovation to a better future. This study focuses on crumb rubber crumb rubber is because the price dropped dramatically, it is because the abundant production of rubber not absorbed by the domestic market, while not accepted overseas markets because of the standard that is outside the country are not met. Therefore, through this research are expected to rubber companies may see weakness during this time until it can raise the standard for the product crumb rubber can be received in a foreign country and can profitable to the farmers in Indonesia.

\section{RESULTS AND DISCUSSIONS}

Stages techno metric problem solving methods in this study are as follows. The first stage is to calculate the power rating using the equation (1):

$$
\mathrm{ST}_{\mathrm{i}}=\frac{1}{10}\left[\frac{\sum_{\mathrm{k}}^{*} \mathrm{t}_{\mathrm{jk}}}{\mathrm{k}_{\mathrm{t}}}\right] \quad \mathrm{k}=1,2, \ldots, \mathrm{k}_{\mathrm{t}}
$$

(1)

The results of the calculation of the power rating can be seen in Table 1, Table 2, Table 3 and Table 4.

Table 1. Calculation Of Rating Sophistication Techno Ware

\begin{tabular}{|c|l|c|c|}
\hline No. & \multicolumn{1}{|c|}{ Specific Criteria } & Score & Rating \\
\hline 1 & Mixing Process & 9 & 0,90 \\
\hline 2 & Coagulation Process & 9 & 0,90 \\
\hline 3 & $\begin{array}{l}\text { loagulating Through } \\
\text { Process }\end{array}$ & 10 & 1 \\
\hline 4 & Latex Breaking Process & 10 & 1 \\
\hline 5 & Drying Process Inspection & 10 & 1 \\
\hline 6 & $\begin{array}{l}\text { Quality } \\
\text { Process }\end{array}$ & 0,80 \\
\hline 7 & Finishing Process & 9 & 0,90 \\
\hline 8 & Material Handling & 10 & 1 \\
\hline 9 & Machine Maintenance & 7 & 0,70 \\
\hline
\end{tabular}

Table 2. Calculation Of Sophistication Rating Human Ware

\begin{tabular}{|c|c|c|c|c|}
\hline No. & $\begin{array}{c}\text { Human Ware Sub } \\
\text { Component }\end{array}$ & Score & Average & Rating \\
\hline & Management & & & \\
\hline 1 & $\begin{array}{l}\text { Ability to overcome } \\
\text { problems associated with } \\
\text { the company. }\end{array}$ & 9 & \multirow{4}{*}{9.50} & \multirow{4}{*}{0.95} \\
\hline 2 & $\begin{array}{l}\text { Ability to manage the } \\
\text { entire workforce. }\end{array}$ & 9 & & \\
\hline 3 & Ability to lead. & 10 & & \\
\hline \multirow[t]{2}{*}{4.} & Ability to make decisions. & 10 & & \\
\hline & Technicians and Assistants & & & \\
\hline 1 & $\begin{array}{l}\text { Ability to understand and } \\
\text { carry out the task. }\end{array}$ & 10 & \multirow{4}{*}{9} & \multirow{4}{*}{0.90} \\
\hline 2 & $\begin{array}{l}\text { Ability of discipline and } \\
\text { responsibility. }\end{array}$ & 8 & & \\
\hline 3 & $\begin{array}{l}\text { Ability to create and } \\
\text { innovate in solving } \\
\text { problems, such as } \\
\text { modifying or cope with an } \\
\text { engine failure. }\end{array}$ & 8 & & \\
\hline \multirow[t]{2}{*}{4} & $\begin{array}{l}\text { Ability to work well } \\
\text { together. }\end{array}$ & 10 & & \\
\hline & Employees & & & \\
\hline 1 & $\begin{array}{c}\text { Effective capacity } \\
\text { utilization for the benefit of } \\
\text { the company }\end{array}$ & 8 & \multirow{2}{*}{7.50} & \multirow{2}{*}{0.75} \\
\hline \multirow[t]{2}{*}{2} & $\begin{array}{c}\text { Effective utilization of } \\
\text { resources in production } \\
\text { activities }\end{array}$ & 7 & & \\
\hline & Mobile workers or laborers & & & \\
\hline 1 & Percentage of set targets. & 9 & 9 & 0.90 \\
\hline 2 & $\begin{array}{l}\text { Completion of the work } \\
\text { that has been set by the } \\
\text { company. }\end{array}$ & 9 & & \\
\hline
\end{tabular}

Table 3. Calculation Of Sophistication Rating Info Ware

\begin{tabular}{|c|c|c|c|c|}
\hline No. & Criteria Specification & Score & Average & Rating \\
\hline 1 & Company Data storage & 5 & \multirow{5}{*}{4.80} & \multirow{5}{*}{0.48} \\
\hline 2 & $\begin{array}{c}\text { Enterprise information } \\
\text { network }\end{array}$ & 5 & & \\
\hline 3 & $\begin{array}{c}\text { Computer facilities in the } \\
\text { production process }\end{array}$ & 3 & & \\
\hline 4 & $\begin{array}{c}\text { Procedures that } \\
\text { facilitate } \\
\text { communication } \\
\text { between all members of } \\
\text { the company }\end{array}$ & 6 & & \\
\hline 5 & $\begin{array}{c}\text { Ability of enterprise } \\
\text { information systems in } \\
\text { support of the } \\
\text { company's activities }\end{array}$ & 5 & & \\
\hline
\end{tabular}


Table 4. Calculation Of Sophistication Rating Organ Ware

\begin{tabular}{|c|c|c|c|c|}
\hline No. & $\begin{array}{c}\text { Criteria } \\
\text { Specification }\end{array}$ & Score & Average & Rating \\
\hline 1 & $\begin{array}{l}\text { Company's } \\
\text { ability to } \\
\text { increase } \\
\text { productivity }\end{array}$ & 8 & \multirow{6}{*}{8.67} & \multirow{6}{*}{0.87} \\
\hline 2 & $\begin{array}{c}\text { Companies } \\
\text { autonomy }\end{array}$ & 9 & & \\
\hline 3 & $\begin{array}{l}\text { Company's } \\
\text { ability to create } \\
\text { an environment } \\
\text { that is conducive } \\
\text { to improvement }\end{array}$ & 8 & & \\
\hline 4 & $\begin{array}{c}\text { Company's } \\
\text { ability to build } \\
\text { relationships } \\
\text { with customers }\end{array}$ & 10 & & \\
\hline 5 & $\begin{array}{l}\text { Vision and } \\
\text { mission of the } \\
\text { company }\end{array}$ & 10 & & \\
\hline 6 & $\begin{array}{l}\text { Company's } \\
\text { ability to work } \\
\text { together with } \\
\text { suppliers }\end{array}$ & 7 & & \\
\hline
\end{tabular}

The second stage is to calculate the contribution of specific criteria using equation (2).

$$
\mathrm{T}_{\mathrm{i}}=\frac{1}{9}\left[\mathrm{LT}_{\mathrm{i}}+\mathrm{ST}_{\mathrm{i}}\left(\mathrm{UT}_{\mathrm{i}}-\mathrm{LT}_{\mathrm{i}}\right)\right]
$$

The result of the calculation of the contribution on specific criteria can be seen in Table 5 .

Table 5. Contribution Criteria Advanced Technology

\begin{tabular}{|c|c|c|c|c|c|}
\hline \multirow[b]{2}{*}{ No. } & \multirow{2}{*}{$\begin{array}{l}\text { Technology Specific } \\
\text { Component }\end{array}$} & \multicolumn{2}{|c|}{$\begin{array}{c}\text { Level of Technological } \\
\text { sophistication }\end{array}$} & \multirow[b]{2}{*}{ Rating } & \multirow[b]{2}{*}{ Contribution } \\
\hline & & $\begin{array}{c}\text { Lower } \\
\text { Control } \\
\text { Limit }\end{array}$ & $\begin{array}{c}\text { Upper } \\
\text { Control } \\
\text { Limit }\end{array}$ & & \\
\hline \multicolumn{6}{|c|}{ Techno ware } \\
\hline 1 & Mixing Process & 3 & 5 & 0.9 & 0.53 \\
\hline 2 & Coagulation Process & 1 & 3 & 0.9 & 0.31 \\
\hline 3 & $\begin{array}{c}\text { Coagulating Through } \\
\text { Process }\end{array}$ & 4 & 6 & 1 & 0.67 \\
\hline 4 & Latex Breaking Process & 5 & 7 & 1 & 0.78 \\
\hline 5 & Drying Process & 3 & 5 & 1 & 0.56 \\
\hline 6 & Quality Inspection Process & 3 & 5 & 0.8 & 0.51 \\
\hline 7 & Finishing Process & 2 & 4 & 0.9 & 0.42 \\
\hline 8 & Material Handling & 5 & 7 & 1 & 0.78 \\
\hline 9 & Machine Maintenance & 1 & 3 & 0.7 & 0.27 \\
\hline \multicolumn{6}{|c|}{ Human ware } \\
\hline 1 & Management & 6 & 8 & 0.95 & 0.88 \\
\hline 2 & Technician and Assistant & 5 & 7 & 0.9 & 0.76 \\
\hline 3 & Employeer & 4 & 6 & 0.75 & 0.61 \\
\hline 4 & Mobile workers/laborers & 1 & 3 & 0.9 & 0.31 \\
\hline \multicolumn{6}{|c|}{ Info ware } \\
\hline 1 & $\begin{array}{c}\text { Processing information } \\
\text { system }\end{array}$ & 3 & 5 & 0.48 & 0.44 \\
\hline \multicolumn{6}{|c|}{ Organ ware } \\
\hline 1 & $\begin{array}{l}\text { Protection frameworks } \\
\text { Companies }\end{array}$ & 4 & 6 & 0.87 & 0.64 \\
\hline
\end{tabular}

The third stage is to calculate the contribution of components using equation (3).

\section{Contributions Component $=\Sigma$ contributions Criteria \\ Specification x Weight

The result of the calculation of the contribution of components can be seen in Table 6.

Table 6. Contribution Component Technology

\begin{tabular}{|c|c|c|c|c|}
\hline $\begin{array}{l}\mathrm{N} \\
\mathrm{o} .\end{array}$ & $\begin{array}{l}\text { Technology } \\
\text { Specific } \\
\text { Component }\end{array}$ & $\begin{array}{c}\text { Criteria } \\
\text { Contributio } \\
n\end{array}$ & Weight & $\begin{array}{l}\text { Component } \\
\text { Contribution }\end{array}$ \\
\hline \multicolumn{2}{|c|}{ Techno ware } & & & \\
\hline 1 & $\begin{array}{c}\text { Mixing } \\
\text { Process }\end{array}$ & 0.53 & 0.11 & \multirow{9}{*}{0.53} \\
\hline 2 & $\begin{array}{c}\text { Coagulation } \\
\text { Process } \\
\end{array}$ & 0.31 & 0.11 & \\
\hline 3 & $\begin{array}{c}\text { Coagulating } \\
\text { Through } \\
\text { Process }\end{array}$ & 0.67 & 0.11 & \\
\hline 4 & $\begin{array}{c}\text { Latex } \\
\text { Breaking } \\
\text { Process }\end{array}$ & 0.78 & 0.11 & \\
\hline 5 & $\begin{array}{c}\text { Drying } \\
\text { Process }\end{array}$ & 0.56 & 0.11 & \\
\hline 6 & $\begin{array}{c}\text { Quality } \\
\text { Inspection } \\
\text { Process }\end{array}$ & 0.51 & 0.11 & \\
\hline 7 & $\begin{array}{c}\text { Finishing } \\
\text { Process }\end{array}$ & 0.42 & 0.11 & \\
\hline 8 & $\begin{array}{l}\text { Material } \\
\text { Handling }\end{array}$ & 0.78 & 0.11 & \\
\hline 9 & $\begin{array}{c}\text { Machine } \\
\text { Maintenanc } \\
\text { e }\end{array}$ & 0.27 & 0.11 & \\
\hline \multicolumn{2}{|c|}{ Human ware } & & & \\
\hline 1 & $\begin{array}{c}\text { Managemen } \\
t\end{array}$ & 0.88 & 0.25 & \multirow{4}{*}{0.64} \\
\hline 2 & $\begin{array}{l}\text { Technician } \\
\text { and } \\
\text { Assistant }\end{array}$ & 0.76 & 0.25 & \\
\hline 3 & Employeer & 0.61 & 0.25 & \\
\hline 4 & $\begin{array}{c}\text { Mobile } \\
\text { workers/la } \\
\text { borers } \\
\end{array}$ & 0.31 & 0.25 & \\
\hline \multicolumn{2}{|r|}{ Info ware } & & & \\
\hline 1 & $\begin{array}{c}\text { Processing } \\
\text { information } \\
\text { system }\end{array}$ & 0.44 & 1 & 0.44 \\
\hline \multicolumn{2}{|c|}{ Organ ware } & & & \\
\hline 1 & $\begin{array}{l}\text { Protection } \\
\text { frameworks } \\
\text { Companies }\end{array}$ & 0.64 & 1 & 0.64 \\
\hline & & \multicolumn{2}{|l|}{ Total } & 2.25 \\
\hline
\end{tabular}


The fourth stage is to calculate the intensity of the contribution of components using equation (4).

Intensity contribution of technology = (Component Contribution):(Component Contribution Sum)

The result of the calculation of the intensity of the component contributions can be seen in Table 7.

Table 7. Calculation Of Intensity Contributions Components

\begin{tabular}{|c|c|c|}
\hline $\begin{array}{c}\text { Technology } \\
\text { Component }\end{array}$ & $\begin{array}{c}\text { Component } \\
\text { Contribution }\end{array}$ & $\begin{array}{c}\text { Component } \\
\text { Contribution } \\
\text { Intencity }\end{array}$ \\
\hline Techno & 0.53 & $0.53 / 2.25=$ \\
\hline Human & 0.64 & $0.64 / 2.25=$ \\
\hline Info ware & 0.44 & $0.44 / 2.25=$ \\
\hline Organ ware & 0.64 & $0.64 / 2.25=$ \\
\hline Total & 2.25 & 1.00 \\
\hline
\end{tabular}

The fifth stage is to calculate the coefficient of technological contribution by using equation (5).

$$
\mathrm{TCC}=\mathrm{T}^{\beta \mathrm{T}} \times \mathrm{H}^{\beta \mathrm{H}} \times \mathrm{I}^{\beta \mathrm{I}} \times \mathrm{O}^{\beta O}
$$

The result of the contribution coefficient calculation technology capabilities can be seen in Table 8.

Table 8. Calculation Of Coefficient Contributions Technology

\begin{tabular}{|c|c|c|c|}
\hline $\begin{array}{c}\text { Technology } \\
\text { Component }\end{array}$ & $\begin{array}{c}\text { Component } \\
\text { Contribution }\end{array}$ & $\begin{array}{c}\text { Component } \\
\text { Contribution } \\
\text { Intencity }\end{array}$ & TCC \\
\hline Techno & 0.53 & 0.24 & \\
\hline Luman & 0.64 & 020 & \multirow{2}{*}{0.57} \\
\hline Infoware & 044 & 020 & \\
\hline Organ ware & 0.64 & 0.28 & \\
\cline { 1 - 3 } Total & 2.25 & 1.00 & \\
\hline
\end{tabular}

Diagram THIO (Technoware, Humanware, Infoware and orgaware) can demonstrate the contribution of existing technologies in the enterprise. THIO diagram can be seen in Figure 1.

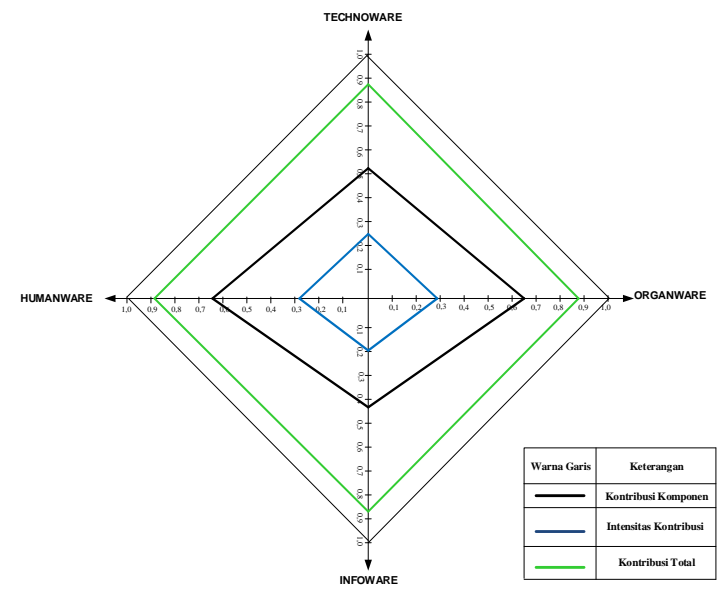

Figure 1. Diagram THIO Contributions Component Technology

Infoware component is a weakness in the company. It is shown that companies still manually calculating the operation of the engine, engine maintenance, engine capacity, state of the machine is running, the amount of which will be produced and the number of monthly requests even safety instructions.

Components technoware, humanware, organware has the largest contribution to the company. Seen from advanced machinery systems, good workers and good working methods.

The intensity of technological component contribution shows the ratio of contribution of a technological component with other components. Components humanware and organware intensity greatest contribution. The next largest component with an intensity that is a component technoware. While infoware components have almost equal intensity.

The Company has a TCC of 0.57. This indicates that the use of technology in general at the company had reached $57 \%$. Companies still need improvements to increase the utilization of the technology that will ultimately have an impact on company productivity. 


\section{CONCLUSIONS}

The conclusion is based on the results of data processing and analysis has been carried out, namely:

1. The contribution of each component are: components technoware $0.53,0.64$ humanware components, parts and components organware infoware 0.44 to 0.64 .

2. Technology Contribution Coefficient company reached 0.57 . This means that companies still need improvements in technology.

3. The intensity contribution component technology companies almost equal in all four aspects. But the improvement priorities focused on aspects of the smallest infoware intensity.

\section{ACKNOWLEDGMENTS}

The authors gratefully acknowledge that the present research is supported by University of Sumatera Utara. Last, but not least thank to my wife, my son and my daughter, without whom I was nothing; they not only assisted me morally but also extended their support emotionally.

\section{REFERENCES}

[1] Hyt"onen H., Jarimo, T., Salo, A., Yli-Juuti, E (2012), Markets for standardized technologies: Patent licensing with principle of proportionality, Technovation 32(2012)523-535.

[2] Yamane, Y., Takahasi, K., Hamada, K., Morikawa,K., $\quad$ Bahagia,S.N, Diawati,L.,Cakravastia, A., (2015), Developing a plant system prediction model for technology transfer. Int. J.Production Economics 166(2015)119128.

[3] Irène Kilubi, Strategic technology partnering: A framework extension, (2015), Journal of High Technology Management Research 26 (2015) 27-37.

[4] Evans, Bill, (1985), Japanese-style management, product design and corporate strategy, Volume 6, Issue 1, January 1985, Pages 25-33.

[5] Kamimoto,H., Endo, K., (1987), Development of a complex mixed production system for plain paper copier machines, Robotics and Computer-Integrated Manufacturing, Volume 3, Issue 4, 1987, Pages 409-416.

[6] Banerjee, J.K., (1997), The gap management, Computers \& Industrial Engineering Volume 33, Issues 1-2, October 1997, Pages 175-178.

[7] Smith, R., (2007)., Understanding and acquiring technology assets for global competition, Technovation, Volume 27, Issue 11, November 2007, Pages 643649.

[8] Nasser Bagheri Moghaddam, N.B., Mousavi, S.M, Nasiri, M., Moallemi, E. A., Yousefdehi H., Wind energy status of Iran: Evaluating Iran's technological capability in manufacturing wind turbines, Renewable and Sustainable Energy Reviews, Volume 15, Issue 8, October 2011, Pages 4200-4211

[9] Hauschild, M.Z., Jeswiet, J., Alting, L., 2004. Design for environment ddo we get the focus right? CIRP Ann. e Manuf. Technol. 53 (1), $1 \mathrm{e} 4$.

[10] Maxwell, D., Sheate, W., van der Vorst, R., 2006. Functional and systems aspects of the sustainable product and service development approach for industry. J. Clean. Prod. 14 (17), 1466-1479.

[11] Ni, Y., Fan, F., Zheng, Y., Zhang, Y., 2011. Value engineering-driven lean product development. Adv. Sci. Lett. 4 (6e7), 2440-2445.

[12] Park, J.-H., Seo, K.-K., 2006. A knowledge-based approximate life cycle assessment system for evaluating environmental impacts of product design alternatives in a collaborative design environment. Adv. Eng. Inf. 20 (2), 147-154.

[13] Porter, M., van der Linde, C., 1995. Green and Competitive, Harvard Business Review: September-October, pp. 120134.

[14] Johansson, G., Magnusson, T., 2006. Organising for environmental 
considerations in complex product development projects: Implications from introducing a "green" sub-project. J. Clean. Prod. 14 (15e16), 1368-1376.

[15] Hong, P., Kwon, H-B., Roh, J.J., 2009. Implementation of strategic green orientation in supply chain: an empirical study of manufacturing firms. Eur. J. Innov. Manage 12 (4), 1460-1060.

[16] Giannopoulou, E., Yström, Ollila, S., Fredberg, T., Elmquist, M., 2010. Implications of openness: a study into (All) the growing literature on open innovation. J. Technol. Manag. Innov. 5 (3), 162-180.

[17] Duflou, J., Dewulf, W., Sas, P., Vanherck, P., 2003. Pro-active life cycle engineering support tools. CIRP Ann. e Manuf. Technol. 52 (1), 29-32.

[18] Donnelly, K., Beckett-Furnell, Z., Traeger, S., Okrasinski, T., Holman, S., 2006. Ecodesign implemented through a product-based environmental management system. J. Clean. Prod. 14 (15e16), 1357-1367.

[19] Cooper, R., Slagmulder, R., 2004. Achieving full-cycle cost management. MIT Sloan Manag. Rev. 46 (1), 45-52.

[20] De Mendonça, M., Baxter, T.E., 2001. Design for the environment (DFE) e an approach to achieve the ISO 14000 international standardization. Environ. Manag. Health 12 (1), 51-56. 